\title{
ANTI-CORRUPTION METHODS
}

\section{Yury Bubnau}

\author{
Mogilev State University of Food Technologies, Mogilev, Belarus
}

CMESTE

JEL Category: D73

\begin{abstract}
The article presents two groups of methods to counter the corruption of public servants. The first part examines the repressive methods of fighting corruption. Such methods include the death penalty, the increase in prison terms, confiscation of the property of the briber, fines, a ban on the profession for corrupt officials. The second part analyzes the strengths and weaknesses of preventive methods to counter corruption. These include dissemination of knowledge about corruption and measures to counter it, transparency and publicity of public procurement, electronic competitions in public procurement, public reporting of public procurement servants. The following methods are also considered: commercialization of the activities of civil servants, increasing salaries for officials, reducing the number of civil servants, reducing bureaucratic functions, minimizing the variability of decisions of officials, the transition from permissive to notifying public institutions, including the one-window principle. The methods such as electronic paperwork, recruitment of personnel taking into account their psychological and moral qualities, checks of civil servants, operational control over the work of officials, rotation of personnel, the method of "circular bail", anonymous survey of employees are also described. Much attention is paid to the participation of the population in the detection of corrupt officials: opinion polls, "trust telephones", public control over the expenditures of officials, providing guarantees to persons who contribute to the detection of corruption. A special role in the fight against corruption of officials belongs to democratic institutions ensuring equality of all members of society under the law, elected officials, as well as the method of the sociocultural discrediting of bribery.
\end{abstract}

Keywords: Corruption. Anti-corruption methods.

\section{INTRODUCTION}

The fight against corruption has been under way for thousands of years. This problem was felt by all societies that have entered the phase of state building. It was with the formation of the state and there was corruption. She is a parasite in the state body, appears, lives and dies with the state. Probably, as a Koch's bacillus lives in every human body, so does corruption in all the states of the world. However, just as a healthy body is able

Address of the corresponding author:

Yury Bubnau

䒠bubnov juri@tut.by to withstand viruses, albeit permanently living in it, there are also states that have managed to reduce corruption to a non-dangerous level for itself. Our country, unfortunately, looks like a patient with metastases, the recovery of which is too slow. The problem of corruption is still extremely relevant for the Belarusian society.

In the fight against bribery, as against any deviation, two main approaches can be taken: repressive and preventive. There is no rigid watershed between them. All repressive measures are also preventive, warning citizens against committing crimes. And yet, there is a fundamental difference between them. The 
repressive measure is aimed directly at the person who has already transgressed the law. This is a way of punishing him for an already committed crime. But the preventive measure is aimed at the citizens who are innocent before the law. It prevents them against committing an offence by creating an environment with the least temptations of illegal acts. We intend to consider these two large groups of methods in this article.

\section{REPRESSIVE ANTI-CORRUPTION METHODS}

Repressive anti-corruption measures are most popular among the people. They include, first of all, tougher sanctions against corrupt officials up to the death penalty. So let's talk about it first. And let's start with the most radical measure - with the death penalty of corrupt officials.

The death penalty for bribes. Even in ancient times, according to Herodotus, in Persia, King Kambiz from the judge-briber ordered alive to tear off the skin and wrap it around the chair for the next judge, so that he always remembered the fate of his predecessor. Not all our contemporaries consider such measures a manifestation of wild barbarism. And today there are many supporters of the use of the death penalty against bribers. In China, for example, even today, corrupt officials are not only condemned for long prison terms, but often shot, showing the execution on TV in the evening news programs in spite of the ranks and positions. In 2000 , for example, even the VicePresident of the National People's Assembly was executed on corruption charges. Of course, the fear of losing a life is a good safeguard against corruption temptations. But is it possible to eliminate corruption as a social phenomenon by the extermination of bribers? Doubt in the effectiveness of even such steep measures of extermination of bribers causes at least the fact that, despite the shootings, bribery in China has not only is reduced to zero, but even, according to the Chinese themselves, is thriving. In any case, in the rating of perception of corruption according to Transparency International for 2019, China was even lower than Belarus (respectively, $87^{\text {th }}$ and $70^{\text {th }}$ place). It seems that the death penalty for bribery is not a panacea for corruption. In our view the thing is that corrupt officials but not corruption are executed. And the difference, as it is easy to understand, is fundamental: if there are favorable conditions for corruption, the heads of bribers will have to be cut endlessly, because it is like the Lernaean Hydra with a thousand heads. The Heracles is cutting of the heads of this hydra, as it is known, led to a doubling of their number. Such efficiency has been observed so far in the most eminent anti-bribery fighters, who have the authority to eliminate corruption among officials, entrusted to the same officials, only from another agency. How can we not remember the sad experience of the fight against the fever of the soon-to-be-killed Russian tsar Peter the Great, all the efforts of whom led, in the end, to the appearance of the unsurpassed briber Alexander Menshikov.

Increase in prison terms. However, our contemporaries in the age of humanism are not so often offered to rip off the skin of bribers and put them on a stake. More often than not, they are referring to an increase in prison terms. But can we increase the terms of imprisonment, if part one of Art. 430 of the Criminal Code of the Republic of Belarus (receiving a bribe) provides up to seven years, part two - up to ten years, and part 3- up to fifteen years in prison. In terms of the severity of sanctions, corruption has already almost been equated with murder, drug and weapons production. It is advisable to toughen the punishment only in relation to those bribers who have a duty to guard the law, first of all, prosecutors and judges. And yet, it seems that the resource of increasing prison terms for bribes has already been exhausted. But there is an opportunity to hurt a corrupt official on the pocket. It's about confiscating the briber's property.

Confiscation of the briber's property. This measure is widely used in many developed countries of the world, including Belarus. Articles 430-431 of the Criminal Code of the Republic of Belarus provide for the possibility of confiscating all or part of the criminal's property. Let's emphasize, not the subject of a bribe, but all the property of the fallen corrupt officials. This measure is good because it devalues the meaning of the corrupter's establishment - the accumulation of material goods. The risk of losing all property can save the most sensible officials from the temptation of corrupt profits. However, it should be recognized that far-sighted corrupt officials find an antidote to this risk by transferring some of the most valuable property in the name of their 
relatives and proxies. Therefore, the effectiveness of this measure is also often highly questionable.

Fines. Recently, in a number of countries, particularly in Russia, as a measure against corruption, it is proposed not to imprison bribers, but to fine them. In April 2011, the State Duma passed a bill introduced by Russian President D. Medvedev, according to which the alternative to prison for bribers are fines. Moreover, the amount of fines is multiplied with the amount of bribes. The bigger the bribe is, the more substantial the fine is. Critics of the measure have justifiably accused its supporters of allowing corrupt officials to pay off their prison sentences. In addition, the judges themselves fall into the corruption temptation of assigning criminals qualitatively different types of punishment. And in terms of social justice, there may be inconsistencies: the poor will still get real terms, and the rich will again get a chance to pay off. In any case, this measure deserves to be tested for economic efficiency and social justice.

Prohibition of the profession for corrupt officials. From various social layers often sounds a proposal to permanently exclude from the register of public servants caught with red-handed bribery. The Criminal Code of the Republic of Belarus 430 (receiving a bribe) provides for depriving the offender of the right to hold relevant positions and engage in certain activities. This kind of "prohibition on the profession" is considered by many to be justified repressive measure, which has a preventive effect (Alekseyev, 2008, p. 4). It is able to keep officials from the corruption temptations that accompany the life of a high-ranking official. Doubt can cause only that the severity of the measure, once and forever finishing the career of the official who took a false step. On the other hand, the inevitability of punishment, combined with its harshness, is a strong caution against committing corruption crimes. So, repressive sanctions of the maximum degree were provided by the national law. There is probably nowhere to tighten the legal screws. But even such severe sanctions do not frighten everyone, as the statistics of offenses and data of sociological studies show. This means that the repressive measures have almost completely exhausted themselves. That doesn't mean they need to be minimized. But also they should be supplemented with preventive measures. We will talk about them in more detail in the next part of the article.

\section{PREVENTIVE ANTI-CORRUPTION MEASURES}

Preventive anti-corruption measures are different from repressive measures in that they are targeted not by criminals but by the conditions that give rise to crime. Accordingly, if repressive measures are used for the most part by law enforcement and regulatory bodies, preventive measures are initiated by public figures and political leaders, and are developed by scientists and social technologists. Preventive measures are being carried out not during special operations of law enforcement agencies, as repressive measures, but within the framework of social policy. Unlike repressive measures, the set of which is severely limited, preventive measures can be inexhaustible. Understanding this, we will try to formulate and summarize some of them.

Expanding and disseminating knowledge on prevention of corruption. This is one of the requirements of the United Nations Convention Against Corruption adopted by the UN General Assembly on 31 October 2003. Training programs for schools and universities should provide future professionals with "specialized and appropriate training in order to increase their awareness of the risks of corruption and their performance". People's knowledge and understanding of what constitutes bribery and what punishments it provides is the foundation of the fight against corruption. Such knowledge serves as an important preventive measure for future public servants and for the entire population, warning them against corrupt interaction. It is for this purpose that a training course entitled "Corruption and its public danger" has been introduced in the programs of all higher education institutions in Belarus since 2009. This course can be called as a training course only conditionally, because its task is not to teach, but to warn against corruption risks, to help future managers to resist the temptations of the authorities. Our experience of teaching this course demonstrates the significant interest of students in the content of the discipline (Bubnov \& Gribanovskiy, 2019, pp. 16-20).

Transparency and publicity of public procurement. This method of minimizing 
corruption is proposed in Art. 9 of United Nations Convention against Corruption, adopted by the UN General Assembly on 31 October 2003. Public procurement decisions are effective measures to prevent corruption. It is impossible to disagree with this. Only if the complex of all procedures that ensure transparency and publicity of public procurement, we can hope to minimize the corruption risks of this truly "pot of gold" of the greedy officials and enterprising businessmen. In Belarus, any significant purchases are carried out on a competitive basis. The level of transparency and publicity of public procurement greatly increases electronic bidding.

Electronic bidding and competitions for the placement of government orders have become widely introduced recently due to the spread of computer technologies. Private business has long mastered the Internet for trading. But government orders began to be placed in the Internet for direct bidding and competitions only relatively recently. And this applies mainly to the Russian experience. To some extent, such slowness in the development of promising technologies can be explained by the inherent sluggishness of the state system. However, it is necessary to take into account the corrupt interests of a certain part of the bureaucracy, which has always had considerable kickbacks on public procurement and orders. Under any pretext, they try to "roll" electronic trades into a behind-the-scenes format, opening for them a wide range of opportunities for corruption "margins".

Public reporting as one of the fundamental principles of the functioning of state organizations, according to Art. 10, the 2003 UN Convention, is one of the conditions preventing corruption. Beginning with the revolutionary reform of Servius Tullius, which made the contents of state laws in the Roman public, publicity became one of the fundamental foundations of the rule of law. This is also the case with corruption, which flourishes in the face of excessive secrecy and the secrecy of public information. More often only unscrupulous officials are interested in such secrecy. According to modern lawyers (Golik \& Karasov, 2005, p. 32), a socially oriented and transparent system of public governing and administration can become a force that can paralyze corruption and effectively control the bureaucracy.
Public participation in the detection of corrupt officials is considered by UN Convention as the most important factor in the success of the problem in identifying corrupt officials. Art. 10 recommends that the public should be provided with all possible channels of access to law enforcement agencies to report, including anonymously, any cases that may constitute any corruption crimes. Indeed, the participation of the population in the active anti-corruption can provide total control over the bribery bureaucracy. So, it might happen if there were no three problems. The first problem is the risk of anonymous slander and personal account information between citizens. And the second, much more significant problem is that, unfortunately, a large part of the population is not interested in uncovering corrupt channels of interaction with compliant officials. There is also a third moral problem. The fact is that in the national mentality it is considered indecent to "signal" to the state authorities about the offenses of fellow citizens. In order for people to want to inform to one government agency about bribes happening in another public body, it is necessary, first, that they should not afraid to do so, secondly, that they should be interested in fighting corruption and, thirdly, that they consider it a noble, decent thing. Unfortunately, so far all three conditions of total people's control over bribers are not in use. It is necessary to work a lot with people to make it an unequivocal ally in the fight against corruption. But if bribery remains a mass social practice, this measure will not result in any obvious results.

Commercialization of state activities. This proposal was made by the well-known economist Gabriel Popov. Being the mayor of Moscow and much later in his activities, he strongly recommended the introduction of "legitimate, transparent, taxable participation of bureaucrats in the share of profits derived from their decisions" (Gutorova \& Trifonov, 2010, p. 4). Thus, the author of the idea believed that officials would be more focused on the interests and needs of customers, getting their livelihoods from them. The legality of paying for the services of officials, according to G. Popov, should save them from a number of social guilt and criminal risks. And the state will be able to receive taxes from official payments of visitors to public servants. Critics of this idea called it as legalization of bribery and resuscitation of medieval practice of "feeding" officials. Moreover, 
such a reform of the public service will hardly save it from corruption, as it would keep intact its main premise - a monopoly dictatorship of bureaucracy.

Increased salaries for government employees. The idea of financially interested officials to be honest is not new. According to results of the survey, one in four citizens of Belarus supports the proposal to legally raise the salaries of civil servants, so that they do not have their eye on the bribe. This idea is often said by the officials. They can be understood. This is a completely win-win option for them to fight against corruption. In Russia, where corruption has reached unprecedented proportions, it is supposed not only to punish bribers, but also to "buy" them with high salaries. In particular, the project is actively promoted, according to which the salaries of state officials should increase much more and reach several thousand dollars. For example, Boris Nemtsov a few years ago proposed to set the salary of the prime minister at the level of 10 thousand dollars, a minister - 7 thousand, the head of the department - 500-600 dollars. The idea of B. Nemtsov has actually been implemented. The authors of the reform were not afraid of the fact that the adoption of their proposals led to a monthly increase in the cost of bureaucracy by 20 million dollars. In his interview Nemtsov said: "It will cost less than to pay the current starvation wage. The Anti-Corruption Committee estimates that the level of the damage caused to the country by corruption, in the form of duty-free import of goods amounts to 20 billion dollars a year. This figure is comparable to Russia's annual budget. With higher salaries the state will be able not only to hire young professionals who are not corrupted by bribes, but also to reduce the apparatus by 20\%" (Samyye interesnyye stat'i, 2005, p. 5). However, the mere increase in the salaries of public servants, as experience has shown, does not produce tangible results. Even with the increased salaries, Russian officials are still taking bribes. It is important not only to increase the salaries of public servants and also it is necessary to give an increase in salary to show government care about the employee and his family. Then it will be taken not for granted, but as an encouragement that still needs to be earned. Today, for example, Belarusian customs officers receive personal allowances for rank, for knowledge of foreign languages, for special conditions of service, for seniority, annual allowances for recovery, etc. So, it is necessary to rise wages to officials, as well as to all other "budget workers," of course. But they should do it wisely.

Reducing the number of officials. One of the most practiced methods of the administrative system to counter corruption is the reduction in the number of officials. And usually one in five civil servants is subject to sequestration. The figure of $20 \%$ seems to have a certain magic, because it is most often announced by the decisive leaders of the states, who turned on corrupt officials among their own employees. The Belarusian President has repeatedly practiced a 20 percent reduction in civil servants in the early years of his governing. In 2013, the President of Belarus demanded 25 percent reduction of the state apparatus. D.A. Medvedev, ex-President of the Russian Federation, emotionally commented on how productive such measures are against bureaucratic corruption: "We are reducing it. Then it's six months - look, and again the same number" (Kuz'min, 2010, p. 2). It is obvious that the mere reduction of public servants is labor of Sisyphus. It is necessary to reduce bureaucratic functions. It is time to talk about it.

\section{Reducing bureaucratic functions.}

Counteracting corruption by reducing the number of officials is like fighting the temperature of a sick person. The boundless growth of the bureaucracy is just a symptom of the dominance of the administrative-command system over civil society. It is necessary to fight not with the symptoms, but with the cause of bureaucracy in the form of corruption, which is the monopoly dominance of the administrative-command system. It is necessary to eliminate not officials, but administrative functions, many of which are useless and harmful. Analysts of the Russian government, for example, have found that almost 1.5 thousand functions of local officials are redundant, i.e. simply, not required, more than 260 of them duplicate each other, and another 700 require clarification of their functional necessity (Kuz'min, 2010, p. 2). It is easy to imagine how many civil servants carry out these useless functions throughout vast Russia. The area of Belarus is much smaller, but this does not mean that the problem of excessive bureaucratic functions is less relevant for us. On the contrary, it 
is more difficult for us to maintain extra officials. Elimination of these unnecessary functions will mean a reduction in the corruption capabilities of the entire bureaucratic class. In addition, the elimination of excess staff will save state budget. But will officials want to surrender their privileges without a fight to control everything and everything, without answering? The question, as they say, is rhetorical.

Minimizing the variability of officials' decisions. One of the prerequisites for corruption is the ability of an official to manipulate his functions. The multiplicity of possible decisions of a public servant can be used by him to obtain corrupt income from persons interested in a particular outcome of the case. For example, the "limits" of penalties of a tax inspector or traffic police officer can be used by unscrupulous employees as a tool to pressure the guilty businessman or motorist for the purpose of obtaining a corrupt benefit. The legal unambiguity in making management decisions and sanctions allows to significantly reduce the corrupt capabilities of the greedy public servants.

The transition from permissive to notification of the registration of public initiatives. The essence of this transition is that the official is deprived of the right to authorize or prohibit a socially significant matter. Its function is only to register the initiative of citizens, for which they themselves are now fully responsible. This transition, already partially implemented in the business registration procedure, was an extremely important step of the state towards eliminating the reasons for corruption in the state authorities. The principle of "one window" in dealing with citizens' statements has become a "visit card" of Belarusian administrative reforms aimed at debureaucratizing the entire state system of our country. Now all the provisional documents necessary for registration prepare the office to which the citizen applied. Along with the reduction of opportunities for unsubstantiated demands on the part of officials their ability to collect from visitors illegal tributes in the form of a bribe has decreased. Thus, a side-by-side, but very important consequence of the introduction of the "one-window" principle was not only the elimination of queues in front of office offices, but also the reduction of conditions for corruption. But, the polls conducted by Mogilev Institute of
Regional Social and Political Studies revealed that the implementation of the "one-window" principle in the work of specific offices still leaves much to be desired. Nevertheless, the direction for improving public services working with the population is correct. It's just about going the course consistently.

Electronic paperwork. A further step towards debureaucratization and ridding officials of the temptations of bribery may be the introduction of electronic paperwork into broad administrative practice. The creation of electronic databases, password-available for operational use by the population and responsible officials, will minimize the personal communication of citizens with officials. And this, in turn, will help "to knock out another stone" from the foundation of bribery. The possibility in principle and expediency of electronic paperwork has been proved by the positive experience of domestic banks, which successfully use computer technologies in the management of citizens' accounts.

Recruitment, considering psychological and moral qualities, is one of the most obvious preventive measures to fight against corruption in state bodies, whose employees work closely with the population. Article 7 of the United Nations Convention against Corruption, adopted by the UN General Assembly on 31 October 2003, suggests the use of "appropriate selection and training procedures for public office, which is considered particularly vulnerable to corruption." In some cases, the verification of applicants for positions of responsibility is carried out in an extended and in-depth mode, when the reputation of relatives and ancestors of the applicant for a responsible position is analyzed. Another fundamental drawback of this method is the imperfection of tests for measuring the psychological and moral characteristics of a person. Until now, scientists have not created a test that would not cause doubts and questions in practitioners. This does not devalue the method itself but limits its effect and prevents the absolutization of test results.

Checks of public servants. First try, then trust. This motto can be applied to many government departments, as most of them have internal security services. The effectiveness of these units can be disputed, but hardly anyone will dare to call 
for their dissolution. The strength of internal staff monitoring services is their deep integration into the workforce. However, the downside is the same. A serious obstacle to the effective operation of the security services can be just their status and socio-psychological involvement in the team of the department, when the struggle for the cleanliness of the uniform can be taken as a basis for sweeping the litter under the carpet, not from the hut. Some high-ranking officials have gone even further in their efforts to purge government agencies. For example, the head of the Internal Affairs Department of the Russian Ministry of Internal Affairs, Lieutenant General Yuri Draguntsov, suggested checking officials for the tendency to take bribes (RG, 2010, p. 9). He was supported by the chairman of the Federation Council Committee on Constitutional Law A. Alexandrov. Such high support for such a radical proposal should demonstrate the legitimate nature of such verification, which many lawyers consider as an unacceptable provocation. In addition to the obvious legal conflict, which will not be easy to solve procedurally for the authors of this proposal, there is another problem, in our opinion, even more significant than the risk of being a provocateur of crime. Proponents of loyalty test for officials assume that the reason for bribery is the subjective propensity of individuals to bribery. They say, there are people who tend to take bribes, and there are those who will never and, in any circumstances, infringe the law. Incorruptible people, of course, exist in the world. Perhaps they will even be enough to form a government of the whole country. However, we consider relying only on the crystal moral qualities of officials as a manifestation of frivolous idealism. Without denying the importance of moral and psychological testing of applicants for public office, we are still more suggesting relying on the creation of objective preconditions that provide the desired model of behavior of officials, regardless of their moral image.

Operational control over the work of officials. According to our data obtained in the course of sociological surveys, one in three respondents told in an anonymous sociological questionnaire that the transfer of so-called "gifts" to officials takes place in their offices. Such practices are bound to be reduced if audio and video control devices are installed in public or unspoken positions at the place of work of officials. Information that such devices can be installed will be a deterrent to the officials from committing illegal acts that threaten their status and reputation. Therefore, video camera simulators can be installed to make the project cheaper. The widespread practice of using this method in developed countries has proven to be effective. The UK leads in number of video surveillance apparatus per capita. Let us remind the erudite reader that it was in this country that the dystopia of J. Orwell's "1984," describing the setting of Big Brother's total visual observation of citizens. If we talk about the method of video surveillance of employees in their workplaces, it is easy to understand the limitations of its use. Corruption in this case will simply move to any other place inaccessible to the all-seeing eye of the state. If we consistently carry out the principle of total observation of people, wherever they are, then dystopia J. Orwell will become a grim reality.

Rotation of officials. One of the factors contributing to corruption is the presence of close ethnic, kinship, friendly, neighbourly, religious and other ties to responsible workers. The more such connections the official has with the social environment and the closer they are, the more difficult it is for him to resist the temptation to please his family and friends bypassing the law. In order to neutralize the social environment, the method of rotation of management personnel is often used considering their ethnic origin and relations. The newcomers are usually freer from the influence of informal social relations and are more often guided by the statute, regulations and other official norms of relations with the population. The problem with this method is only that people tend to quickly start new friends, friends and neighbors, to find among the social environment tribesmen and co-believers. Therefore, the rotation of responsible personnel must be carried out periodically and systematically, which requires additional organizational efforts and material costs. Possible risks as a result of this method should also be noted. If ethnic or religious characteristics are chosen as the main criteria for rotation, this could provoke conflict.

The mutual responsibility method. Mutual responsibility should be used to destroy corruption. It can be created based on responsible 
recommendations of working employees of government agencies to each newly recruited employee. G. A. Vasilevich (2009, p. 14), the Prosecutor General of the Republic of Belarus, made a proposal to guarantee at least two persons when appointing candidates for senior positions. In Russia, we intend to go even further in carrying out this principle. They are going to recruit all law enforcement officers on the recommendations of at least two honored employees. The responsibility of the officials who made the recommendations to the fined employee would lead to their dismissal from service. Similar proposals are discussed in the Russian press. The expediency of using the anti-corruption mutual responsibility method in domestic agencies is obvious. At the same time, however, it is worth considering the possible negative consequences of this method. It can "cement" the mutual responsibility of existing corrupt communities within certain state structures, turning them into impregnable fortresses for external disclosure.

Anonymous questioning of employees of a state structure is a very "edged" tool against corrupt employees. In any collective there will be honest and responsible citizens who do not agree to put up with the bribery of their colleagues. However, due to various circumstances, including pure conventions of a pseudo-moral nature, honest workers may not be able to contribute to the identification of corrupt officials among their colleagues in an otherwise, as only anonymous way. Anonymous questionnaires can become an acceptable channel of information for management about the presence of unscrupulous employees in the staff. However, these "edged" tools should be treated with extreme caution. Motivation of colleagues who report in an anonymous questionnaire about the available facts of corruption can be quite different. It is necessary to consider the probability of slander and personal account information between competing employees. Therefore, the information obtained through an anonymous questionnaire must be double-checked by other methods. The manager, who decided to apply an anonymous questionnaire of employees, should be ready for aggravation of interpersonal relations between them and deterioration of the moral and psychological climate in the team. It is also important to remember that anonymous questionnaire work should be done by a thirdparty independent organization that is not interested in the results of the survey. She will choose the interview methodology that best ensures his anonymity. For all the difficulties and possible negative consequences of the method of anonymous questionnaire, it is worth using from time to time, because even the very probability of such a survey will be a serious warning for the people in the team.

Opinion polls. In our opinion, this is the most effective method of identifying corrupt officials in the structures of state power. The essence of it consists in periodic sample anonymous surveys of the population about the quality of work of certain departments. This method differs from the anonymous questionnaire of employees the minimum probability of slander on the part of respondents. The mass nature of the questionnaire ensures that the assessments of the work of a public body or even an individual official are as objective as possible. The limitation of the methodical nature here is only one thing: independent organizations and professional research groups should conduct opinion polls.

"Trust phones". This is another method based on the use of the feedback principle. Citizens are given the opportunity to inform the authorized body of all illegal or immoral actions of officials by the "trust telephone". This feedback channel can function both anonymously and personified. In addition to the phone, books of comments and suggestions are also often used. This feedback format is most formalized. The comment books and suggestions are the kind of official document with a special procedure for registering and responding to available records. This is the undoubted advantage of these books, which prevents individuals from ignoring or falsifying their contents. But this is also their obvious drawback. Our fellow citizens are often still afraid to leave personalized remarks about bribery of officials. Any significant official causes fear and awe among most of our compatriots. Few people are at risk of complaining about their own name and address. Therefore, the anonymous feedback format remains preferable.

Control of the official's expenses. The official's income can be found out by his expenses. This logic is based on the method of controlling the 
income of officials by voluntarily or forcibly providing them with declarations of property available to them and their immediate family. Indeed, why take bribes, if they cannot be spent on their own needs or on the needs of the family? Providing declarations of property by the officials is one of the most effective means of countering corruption. Article 19 of the Anti-Corruption Act obliges citizens who have entered the civil service, as well as civil servants and their families, to provide declarations on income, property and sources of money to the government agency. Failure to provide a declaration of income and property or intentionally input incomplete, inaccurate information is the reason for refusal to accept public service, appointment of a public servant to another public office or to bring him to disciplinary responsibility, including his dismissal. The challenge of applying this measure is to monitor the credibility of the income and expenditure information provided by the official. Total checks of declarations are too overhead for the budget itself. The thing to do is to rely on random checks. But at the same time, sanctions for an unscrupulous official should be fatal in the status sense.

Modern technology allows you to control budget officials using their card accounts. The general transition of Belarusians to electronic card payments on all types of payments has already made it possible to control the income and expenses of all citizens, including officials. We need to legislate the right of the employer to dismiss from the post of employee, who is unable to explain the discrepancy between his expenses and income. The negative consequence of the mass application of such a measure will be the strengthening of total control over the individual, the reduction of the scope of private life of people, as well as, perhaps, a further increase in the influence of the administrative-command system of a new type.

Guarantees to those who contribute to the detection of corruption. Corruption crimes related to bribery have specifics that prevent their high disclosure. This feature is that in most cases they are the interaction of the two main actors - the briber and the bribe-taker, equally interested in covering up the corrupt act. It is particularly important to destroy common interests of corrupt accomplices, giving them a chance to avoid criminal responsibility. This possibility is provided by the Belarusian law in Article 23 of the AntiCorruption Act states. This rule is also stated in Art. 431 of Criminal Code of the Republic of Belarus. In some cases, the amount of the bribe may even be returned to its owner. Thanks to the ability of one of the parties to corrupt cooperation to avoid criminal prosecution, many crimes were solved, which justifies the dubious "volunteer" confessions of some hapless bribers and bribetakers.

Equality before the law. One of the most important preconditions for corruption is the sense of permissiveness and impunity that often arises from high-level bosses. When the law is harsh only in relation to ordinary citizens, and the ruling elite is outside its sphere of its scope, corruption at the top-level officers increases, infecting the whole society to the bottom. Fish, as you know, rots from the head. Therefore, it is necessary to cleanse society of bribery, starting from the very top of the bureaucratic pyramid. Countries with developed democracies here also give a head start to our transitional society, not leaving their high-ranking officials alone. In Israel, for example, even President Weizmann was under investigation for corruption and was forced to resign for that reason. Former German Chancellor - the unifier of the Germans - G. Kohl, despite all his undisputed merits to the nation, also fell under the article about financial fraud, although he was glad not about himself, but about his native party. Such precedents, widely replicated by free media, can rid any member of the political elite, let alone regional leaders or ordinary officials, of the integrity syndrome. The most important condition for ensuring equality before the law of all layers of the population, including political leaders, is a real democracy. Elections by the population of executive and legislative leaders of the state government, as well as other persons important for public life, such as judges and heads of municipal law enforcement agencies, will help to clean away from corrupt administrative apparatus at all levels.

The election of officials. One of the most effective barriers to public service corruption is the elective principle of the allocation of critical posts. Such positions include not only senior officials of the executive and representative branches of government in the centre and in the field, but also 
judges, heads of municipal supervisory and law enforcement agencies. However, the introduction of this principle is advisable only on the social basis prepared by the long experience of real democracy. People accustomed to living under the auspices of authoritarianism may very soon fall into the trap of pseudo-democracy when mafia cliques will carry power behind the screen of the electoral process. The transitional form to the election of the top officials can serve as the law's right of the population to declare public distrust of an incompetent or bribery official. The possibility of such a kind of "impeachment" can serve as a warning to civil servants who might be engaged in bribery.

The method of sociocultural discrediting of bribery. During sociological research, we found that the corrupt regime of interaction with officials is more typical for successful businessmen. This may indicate a high status of bribery among entrepreneurs. The activities the successful businesspeople realize becomes a kind of benchmark for business neophytes. Therefore, in the fight against bribery, it is important to discredit the corrupt style of interaction between civil servants and ordinary citizens. To do this, a special program of measures to discredit bribery should be envisaged in order to bring it beyond not only the legal consciousness, which is already taking place from a formal point of view, but also beyond the acceptable moral norm. The media, especially television, should play a special role in this matter. It can be satirical social advertising (rather, anti-advertising), and serious analytical programs. The specific format of each individual measure to discredit bribery should be determined by experts in the relevant industry of ideological and advocacy. It is important that ideological and propaganda pressure on the corrupt consciousness was constant and ubiquitous, carried out mainly not by the "frontal" method, but using subtle psychological tools. And we need to be prepared for the fact that this work is for decades, because, as Karl Marx said, the human skull is the most impregnable fortress. However, considering the testimony of Professor Preobrazhensky from "The Dog's Heart" by Mikhail Bulgakov that "the devastation begins in the heads", society should be treated from corruption by forming anticorruption consciousness.

\section{CONCLUSION}

Our task in this text was to give the fullest possible list of all anti-corruption measures, with a brief description and, if possible, an assessment of the effectiveness of each method. This work makes sense, even for organizing the existing methods and creating a data bank on anti-corruption measures.

Conventionally, we have divided all anti-corruption measures into repressive and preventive measures. These two approaches can and probably should complement each other, so both of these approaches need to be used in real social policies to combat corruption. However, the specific weights of these approaches in the specific anti-corruption activities of the current Belarusian government have been significantly shifted towards an administrative and repressive approach. To a certain extent, this has provided positive results. According to Transparency International, Belarus has become "cleaner" in the corruption sense since 2016 almost twice (in 2016 - 119th place, and in 2019 - 70). However, to be in the 70th place for our country in terms of corruption is not honorable, given that the nearest western neighbors occupy much higher places: Poland - 36th place, Lithuania - 38th place. We strongly believe that preventive anti-corruption measures, primarily based on more active involving of people through democratic institutions should be taken on a state-wide scale. Only in this way the Belarusian society will have a chance to become one of the "cleanest" countries in the world, which, by the way, simultaneously tops the ratings of people's well-being.

\section{WORKS CITED}

Alekseyev, A. (2008). Prezumptsii protiv korruptsii. Zakonnost'(4), 4.

Bubnov, Y., \& Gribanovskiy, S. (2019). Sotsial'naya effektivnost' kursa lektsiy po distsipline "Korruptsiya i yeye obshchestvennaya opasnost'". Vysheyshaya shkola(4), 16-20. 
Golik, Y., \& Karasov, V. (2005). Korruptsiya kak mekhanizm sotsial'noy degradatsii. SPb: Yurid. Tsentr Press.

Gutorova, M., \& Trifonov, A. (2010, 02 10). Gavriil Popov otsenivayet znacheniye korruptsii. I predlozhil zainteresovat' byurokratov pribyl'yu. Gazeta "Kommersant"(23), 4. Retrieved from https://www.kommersant.ru/doc/1319268

Kuz'min, V. (2010, 09 23). Minus sto tysyach. Rossiyskaya gazeta.

RG. (2010, 09 30). Dat', vzyat', sest'. Rossiyskaya gazeta(221), p. 9. Retrieved from https://rg.ru/2010/09/30/provokacia.html

Samyye interesnyye stat'i. (2005). Argumenty i Fakty.(28), 5. Retrieved from https://aif.ru/gazeta/number/20772

Vasilevich, G. (2009). Korruptsiya i problemy vozmeshcheniya ushcherba. Respublika Belarus'v sisteme mezhdunarodnykh ekonomicheskikh otnosheniy. Minsk: Pravo i ekonomika.

Received for publication: $\quad 25.02 .2020$

Revision received: $\quad 25.04 .2020$

Accepted for publication: $\quad 01.07 .2020$

\section{How to cite this article?}

Style - APA Sixth Edition:

Bubnau, Y. (2020, July 15). Anti-corruption methods. (Z. Cekerevac, Ed.) MEST Journal, 8(2), 36-46. doi:10.12709/mest.08.08.02.05

Style - Chicago Sixteenth Edition:

Bubnau, Yury. 2020. "Anti-corruption methods." Edited by Zoran Cekerevac. MEST Journal (MESTE) 8 (2): 36-46. doi:10.12709/mest.08.08.02.05.

Style - GOST Name Sort:

Bubnau Yury Anti-corruption methods [Journal] // MEST Journal / ed. Cekerevac Zoran. - Belgrade Toronto : MESTE, July 15, 2020. - 2 : Vol. 8. - pp. 36-46.

Style - Harvard Anglia:

Bubnau, Y., 2020. Anti-corruption methods. MEST Journal, 15 July, 8(2), pp. 36-46.

Style - ISO 690 Numerical Reference:

Anti-corruption methods. Bubnau, Yury. [ed.] Zoran Cekerevac. 2, Belgrade - Toronto : MESTE, July 15, 2020, MEST Journal, Vol. 8, pp. 36-46. 